UDC 314.02

LBC 60.74

\title{
DEVELOPMENT OF TOOLS FOR CONDUCTING CONTENT ANALYSIS OF FEDERALAND REGIONAL MASS MEDIA IN RUSSIA ON THE ISSUES OF REFLECTING THE DEMOGRAPHIC SITUATION AND POLITICS ${ }^{1}$
}

\author{
Tamara K. Rostovskaya \\ Institute for Demographic Research - Branch of the Federal Center of Theoretical and Applied Sociology \\ of the Russian Academy of Sciences, Moscow, Russian Federation
}

\section{Ekaterina N. Vasilieva}

Volgograd State University, Volgograd, Russian Federation; Institute for Demographic Research Branch of the Federal Center of Theoretical and Applied Sociology of the Russian Academy of Sciences,

Moscow, Russian Federation

\section{Ekaterina A. Knyazkova}

Institute for Demographic Research of the Federal Center of Theoretical and Applied SociologyBranch of the Russian Academy of Sciences, Moscow, Russian Federation; Russian State University for the Humanities, Moscow, Russian Federation

\section{Elena O. Danilova}

Volgograd State University, Volgograd, Russian Federation

Abstract. At the present stage, the development of scientific tools that allow for a qualitative and independent assessment of the current demographic situation and the socio-political measures taken to strengthen, stabilize and develop it is particularly relevant. The efforts of Federal, regional and local authorities ined at increasing population reproduction, increasing the birth rate, reducing mortality, increasing life expectancy, and supporting young families and families with children should be publicized, developed as public initiatives, and resonated with the population. The content analysis method as a method of qualitative and quantitative study of information sources, which implies search, registration, numerical processing of semantic units of analysis, interpretation of the obtained data, and has successfully proven itself in the sociopolitical sphere, can be used for demographic research, including identifying the level of loyalty of public institutions (including the media) to the demographic policy. In the context of media policy, it is important that information related to the demographic situation, especially in Federal and regional media, be objective, reliable, and consistent. This article presents a method of content analysis developed for the purpose of analyzing Federal and regional media in Russia on the issues of reflecting the demographic situation and taking measures of demographic policy. The article provides an overview of the research tools: sample, indicators and keywords, instructions for research and analysis, units of analysis (revealing demographic problems in the Russian Federation, measures to support families at the birth of children, assistance to the older generation and other demographic problems in the mass media).

Key words: content analysis, demographic behavior of the population, demographic situation, demographic policy, research tools, mass media. 


\title{
РАЗРАБОТКА ИНСТРУМЕНТАРИЯ ДЛЯ ПРОВЕДЕНИЯ КОНТЕНТ-АНАЛИЗА ФЕДЕРАЛЬНЫХ И РЕГИОНАЛЬНЫХ СМИ В РОССИИ ПО ВОПРОСАМ ОТРАЖЕНИЯ ДЕМОГРАФИЧЕСКОЙ СИТУАЦИИ И ПОЛИТИКИ ${ }^{1}$
}

\author{
Тамара Керимовна Ростовская \\ Институт демографических исследований ФНИСЦ РАН, г. Москва, Российская Федерация \\ Екатерина Николаевна Васильева \\ Волгоградский государственный университет, г. Волгоград, Российская Федерация; \\ Институт демографических исследований ФНИСЦ РАН, г. Москва, Российская Федерация
}

\section{Екатерина Александровна Князькова}

Институт демографических исследований ФНИСЦ РАН, г. Москва, Российская Федерация; Российский государственный гуманитарный университет, г. Москва, Российская Федерация

\section{Елена Олеговна Данилова}

Волгоградский государственный университет, г. Волгоград, Российская Федерация

\begin{abstract}
Аннотация. На современном этапе особую актуальность приобретает разработка научного инструментария, позволяющего проводить качественную и независимую оценку текущей демографической ситуации, предпринимаемых социально-политических мер по ее укреплению, стабилизации и развитию. Усилия властей федерального, регионального и местного уровней, направленные на увеличение воспроизводства населения, рост рождаемости, снижение смертности, увеличение продолжительности жизни, поддержку молодых семей, семей с детьми, должны информационно освещаться, развиваться в виде общественных инициатив, находить отклик у населения. Метод контент-анализа как метод качественно-количественного изучения источников информации, подразумевающий поиск, регистрацию, числовую обработку смысловых единиц анализа, интерпретацию полученных данных, и успешно зарекомендовавший себя в социальнополитической сфере, может применятся для проведения демографических исследований, в том числе выявления уровня лояльности общественных институтов (включая СМИ) к проводимой демографической политике. В условиях медиатизации политики важно, чтобы информация, касающаяся демографической ситуации, представленная особенно в федеральных и региональных СМИ, отличалась объективностью, достоверностью, непротиворечивостью. В данной статье представлена методика контент-анализа, разработанная с целью анализа федеральных и региональных СМИ в России по вопросам отражения демографической ситуации и предпринимаемых мер демографической политики.В итоге сделан обзор инструментария исследования: выборка, индикаторы отбора текстов по ключевым словам, инструкции включения текста в массив, подлежащий анализу, единицы анализа (понятия, которые раскрываются в статьях, посвященных демографическим проблемам в РФ; поддержке семей при рождении детей; помощи старшему поколению и другие логически-связанные семантические выражения о проблемах демографии, раскрывающиеся в СМИ).

Ключевые слова: контент-анализ, демографическое поведение населения, демографическая ситуация, демографическая политика, инструментарий исследования, средства массовой информации.
\end{abstract}

Методика разработки инструментария социологического исследования методом контент-анализа, используемая в работе, не противоречит сложившейся социологической традиции [Троцук 2017; Allman 2019; Cluley 2016;
Ernst 2009; Zablocki 2013]. В качестве основы для разработки инструментария проведения контент-анализа федеральных и региональных российских СМИ по вопросам отражения демографической ситуации и политики нами оп- 
ределены объект, предмет, цели и задачи исследования.

Объект - демографические проблемы в РФ, сообщаемые федеральными и региональными СМИ.

Предмет - контекст освещения в федеральных и региональных СМИ актуальных демографических проблем.

Цель: провести анализ контента федеральных и региональных средств массовой информации по освещению демографических проблем в Российской Федерации посредством контент-анализа.

Задачи:

1. Разработать перечень российских СМИ федерального и регионального уровней, участвующих в исследовании.

2. Выделить новости, публикации, статьи российских СМИ федерального и регионального уровней, которые посвящены демографическим проблемам в Российской Федерации.

3. Провести контент-анализ.

4. Выявить контекст информационных сообщений в региональных и федеральных СМИ по вопросам демографической ситуации в стране.

5. Сравнить и проанализировать эмпирические объекты исследования (популярные новостные федеральные и региональные издания) с точки зрения освещения демографической ситуации в стране.

6. Полученные данные контент-анализа федеральных и региональных СМИ в России сопоставить с данными паспорта национального проекта «Демография», сделать выводы о характере информационного освещения основных задач данного нацпроекта.

Первым этапом исследования необходимо считать этап интерпретации и операционализации основных понятий, используемых в контент-анализе.

Демография (demography) - это область научного знания, изучающая население, включая его численность, состав (возрастной, половой, по роду деятельности и т. д.) и социологические показатели (коэффициент рождаемости, коэффициент смертности и т. д.) [Бизнес. Толковый словарь 1998]. В Концепции демографической политики Российской Федерации до 2025 г. перечислены цели ее реали- зации: увеличение продолжительности жизни населения, сокращение уровня смертности, рост рождаемости, регулирование внутренней и внешней миграции, сохранение и укрепление здоровья населения и улучшение на этой основе демографической ситуации в стране [Об утверждении Концепции... web]. Кроме того, в паспорт национального проекта «Демография» включены следующие федеральные проекты: «Финансовая поддержка семей при рождении детей», «Содействие занятости женщин - создание условий дошкольного образования для детей в возрасте до трех лет», «Старшее поколение», «Укрепление общественного здоровья», «Спорт - норма жизни». Поэтому в инструментарии контент-анализа необходимо особое внимание уделить следующим индикаторам: рождение детей, здоровье семьи, образование детей, материальный достаток семьи, забота о старшем поколении, продолжительность жизни человека, семейные традиции [Паспорт национального проекта «Демография»].

В соответствии с Законом РФ от 27.12.1991 № 2124-1 (ред. от 01.03.2020) «О средствах массовой информации» под средством массовой информации понимается «периодическое печатное издание, сетевое издание, телеканал, радиоканал, телепрограмма, радиопрограмма, видеопрограмма, кинохроникальная программа, иная форма периодического распространения массовой информации под постоянным наименованием (названием). СМИ федерального / регионального уровня (средства массовой информации, mass media) - это в совокупности газеты, журналы, радио, телевидение, интернет-издания и т.п., которые обращены к массовой аудитории, общедоступны и имеют влияние на идеологическое, политическое, экономическое или организационное воздействие на мнение и поведение человека [Большая актуальная политическая энциклопедия 2009].

Массовая российская пресса выполняет в основном информационную функцию, публикуя те или иные демографические новости, а также обращаясь к темам сенсационного характера, житейским историям. В целом же роль массовой прессы в освещении демографических вопросов еще недостаточно велика. Хотя стоит отметить, что сегодня региональная печать стала заметно активнее в этом 
плане, сосредоточиваясь на местных программах и региональных демографических проектах, острых социально-экономических последствиях демографического кризиса в своих регионах, способах их исправления. Например, последовательно и разнообразно рассматриваются вопросы государственной демографической политики на специальных страницах газеты «Известия». Возросло и число сайтов в интернет-пространстве, где специалисты и общественность обсуждают состояние демографических процессов в стране [Вакуленко web]. Федеральные и региональные СМИ освещают проблемы демографии, вопросы реализации демографической политики, следовательно, есть возможность проведения контент-анализа с помощью анализа новостных сообщений: частоты упоминания в них вопросов, отнесенных к смысловому полю демографии и демографической политики, их анализ и интерпретация. К тому же, контентанализ отражает скрытый смысл в различных статьях и неосознанный взгляд автора / авторов СМИ на описываемые проблемы посредством выявления настойчивого повторения характерных словосочетаний.

На втором этапе исследования необходимо определить направления демографии, демографической политики, их основные смысловые категориальные единицы для проведения контент-анализа. При их определении видится важной постановка исследовательских вопросов, позволяющих привести исследование к логическому завершению, а также обобщить нерешенную проблему, исследуемую с помощью анализа материалов СМИ.

Приведем примеры выделяемых нами смысловых категориальных единиц для проведения контент-анализа и соответствующие им исследовательские вопросы.

Продолжительность жизни: образ жизни, наследственность, уровень здравоохранения. Образ жизни: совокупность условий жизни, форма бытия, проявляющаяся в интересах, деятельности, убеждениях. Важным элементом образа жизни является отношение к здоровью как ценности. Наследственность: заболевания, возникновение и развитие которых связано с различными дефектами и нарушениями в наследственном аппарате клеток. Уровень здравоохранения: качество предоставления услуг населению в области здравоохранения. Исследовательский вопрос: как можно охарактеризовать качество жизни россиян по публикациям в СМИ? Как можно охарактеризовать качество здравоохранения в РФ по публикациям в СМИ?

Снижение рождаемости: изменение отношения в обществе к детям, неуверенность в своем будущем, повышение роли женщины в обществе. Изменение отношения в обществе к детям: молодые люди репродуктивного возраста хотят жить для себя. $\mathrm{He-}$ уверенность в своем будущем: переживания за свое материальное положение. Повышение роли женщиины в обществе: женщины поздно решаются завести ребенка. Исследовательские вопросы: упоминаются ли в СМИ эти тенденции? Как часто в СМИ упоминается институт семьи? Чаще в СМИ институт семьи упоминается в позитивном или негативном ключе?

Высокая смертность: сердечно-сосудистые заболевания, онкологические заболевания, смертность от внешних причин. Сердечно-сосудистые заболевания: болезни с функциональным расстройством работы миокарда, сосудов, артерий и вен. Онкологические заболевания: патологии, характеризующееся образованием злокачественных опухолей (очень опасных для жизни) различной локализации и размера из клеток эпителия разных органов любых систем организма. Болезни органов пищееварения: желудка, поджелудочной железы, кишечника инфекционного и неинфекционного характеров. Инфекичонные и паразитарные болезни, включая коронавирусы, а также экзотические болезни. Болезни органов дыхания вследствие инфекционных и вирусных заболеваний, травм и химических поражений, аллергических раздражителей и др. Смертность от внешних причин: причины, которые вызваны не болезнями, а различными внешними воздействиями. Исследовательский вопрос: какие основные причины высокой смертности населения освещаются в СМИ?

Детская смертность: внешние причины смерти, новообразования, врожденные аномалии. Внешние причины смерти: травмы, самоубийства и убийства. Новообразования: 


\section{СОЦИОЛОГИЯ И СОЦИАЛЬНЫЕ ТЕХНОЛОГИИ}

доброкачественные и злокачественные новообразования, развивающиеся из различных тканей, в том числе эмбриональных. Врожденные аномалии: пороки развития, влекущие за собой выраженные изменения строения и функций органов или тканей. Исследовательские вопросы: как освещены вопросы здоровья детей в СМИ? Уделяется ли этой проблеме достаточно внимания?

Рост числа абортов: по желанию, по медицинским показаниям, угроза здоровью женщины, различные социальные проблемы. Аборты по желанию: на небольшом сроке до 12 недели от зачатия. Аборты по медиизинким показаниям вследствие наличия угрозы здоровью женщины и / или наличие патологии у эмбриона. Угроза здоровью женщины: состояние, при котором возникает риск отторжения зародыша от эндометрия матки. Различные сочиальные проблемы: сложные жизненные ситуации, послужившие основаниями для принятия решения об аборте. Исследовательский вопрос: имеет ли место общественное обсуждение допустимости абортов в СМИ (обсуждаются ли проблемы вмешательства в частную жизнь женщины, религиозных установок и т. д.)?

Причины отказа от деторождения. Многие семьи в России хотят родить детей, однако не имеют возможности сделать это изза отсутствия средств для дальнейшего воспитания ребенка / собственного жилья или др. Каким образом СМИ подчеркивают важность этой проблемы? Иногда люди репродуктивного возраста, даже имея желание и возможность пополнить свою семью ребенком, не могут себе этого позволить по независящим от них факторам. Сколько раз в российских СМИ упоминаются проблемы граждан с бесплодием / медицинскими противопоказаниями к зачатию? Как проходит общественное обсуждение современных технологий вспомогательной репродуктивной медицины и др.? Кто лидеры мнений?

Смертность людей пожилого возраста. Давно известно, что современный человек умирает не «от старости», а от болезней, физического износа организма, осложнений, связанных с ослаблением иммунитета и мутациями, связанными с ростом раковых клеток, а также внешних причин. Многие люди не проживают даже года после официального выхода на пенсию. Как СМИ описывают данную ситуацию? Имеются ли в России источники для развития активного долголетия?

Меры по улучшению демографической ситуации в РФ. Пропаганда семейных ценностей. Финансирование системы здравоохранения. Материальная помощь семьям с детьми. Правительство в последнее время уделяет особое внимание развитию системы здравоохранения, оказывает социальную помощь семьям с детьми. Как часто в СМИ уделяется внимание этой теме? Находит ли поддержку идея стимулирования деторождения материальным и финансовым стимулированием? Пропаганда счастливой семьи с ребенком: СМИ - это мощный рычаг управления мнением большинства. Часто ли в СМИ можно заметить положительно направленную пропаганду семейных ценностей, материнства, отцовства, детства, многопоколенной семьи, молодой семьи, многодетной семьи, ценности первого брака?

Брак и семья: желание создать семью, возраст вступления в брак,проживание в нуклеарной (простой) или расширенной (сложной) семье. Отношение молодежи к людям, создавшим семью: негативное, нейтральное, позитивное. Исследовательские вопросы: есть ли у молодежи желание создать семью? В каком возрасте молодежь желает создать/создает семью? В каком возрасте вступают в брак в России? Как часто молодые семьи проживают с родителями и по каким причинам?

Доход семьи: работа, нужды. Исследовательские вопросы: удовлетворяет ли россиян их работа? Хватает ли им дохода на все необходимые нужды? Как часто семьи мигрируют по экономическим причинам?

Хобби, досуг, путешествия. Исследовательские вопросы: какая роль отводится хобби, досугу, путешествиям в жизни современного человека? Может ли российская семья позволить себе путешествия? Оказывает ли государство помощь семьям в организации семейного досуга, детского отдыха, туризма и оздоровления? Доступны ли они среднестатистической семье?

Ребенок: отношение к детям, количество детей, проблемы детей, оставшихся без попечения родителей, детей-инвалидов, детей, подвергшихся насилию, состоящих в конфлик- 
те с законом, социально и педагогически запущенных детей. Исследовательские вопросы: защищено ли в России детство? Защищены ли права и интересы российских детей, с точки зрения СМИ? Как представлено общественное обсуждение оптимального количества детей в семье? Соответствует ли позиция СМИ общегосударственным интересам? Кто должен защищать интересы ребенка, по мнению СМИ? Какова роль семьи, детского сада, школы, полиции, органов опеки и попечительства, комиссии по делам несовершеннолетних и защите их прав и др. в обеспечении прав и защите законных интересов ребенка? Справляются ли они со своими функциями?

Воспитание. Какие темы социализации и воспитания детей освещаются в СМИ? Отношение к однополым бракам: освещается ли тема однополых браков в СМИ? Чайлдфри (англ. Childfree - свободный от детей; англ. Child less by choice, voluntary child less - добровольно бездетный)? Отношение к религии: какое место занимает религия в семье? Веротерпимы ли современные молодые люди? Какова роль отца в воспитании детей?
На третьем этапе исследования необходимо определить эмпирические объекты исследования, выборку. В ходе контентанализа будут изучаться статьи федеральных и региональных СМИ, представленные в открытом доступе в сети Интернет. Для данного исследования мы определили совокупность текстов, потому как изучение письменных статей, содержащих концентрированный и скомпонованный поток информации рациональнее всего расходует ресурсы исследования. В ходе контент-анализа будут изучаться федеральные и региональные СМИ, представленные в таблице 1. Здесь в качестве примера представлены СМИ субъекта Российской Федерации - Волгоградской области. Однако для реализации цели исследования будет осуществлена выборка СМИ по всем субъектам Российской Федерации. Следует отметить, что выборочные материалы должны включать в себя все отобранные смысловые категориальные единицы и быть опубликованы в один и тот же период времени (выбранный временной интервал в нашем исследовании - 2019-2020 гг.).

Таблица 1

Эмпирические объекты исследования, отобранные для контент-анализа: федеральные и региональные СМИ

\begin{tabular}{|c|c|}
\hline $\begin{array}{c}\text { Наименован ие } \\
\text { СМИ, интернет- } \\
\text { адрес }\end{array}$ & Выборочные матер иалы (статьи), интернет-адрес \\
\hline $\begin{array}{c}\text { «Аргументы и } \\
\text { Факты» (АиФ), } \\
\text { http://aif.ru }\end{array}$ & $\begin{array}{l}\text { «Почему Россия вымирает?» } \\
\text { https://aif.ru/money/есопоту/pochemu_rossiya_vymiraet } \\
\text { «Росстат назвал регионы с самой большой убылью населения» } \\
\text { https://aif.ru/society/rosstat_nazval_regiony_s_samoy_bolshoy_ubylyu_naseleniya } \\
\text { «Как убедить молодёжь больше рожать?» } \\
\text { https://aif.ru/society/opinion/kak_ubedit_molodyozh_bolshe_rozhat } \\
\text { «Родить в 11. Пять историй o раннем материнстве» } \\
\text { https://aif.ru/society/people/rodit_v_11_chetyre_istorii_o_rannem_materinstve } \\
\text { «Как родить внучке тётушку. Мам за 50 становится всё больше» } \\
\text { https://aif.ru/health/life/kak_rodit_vnuchke_tyotushku_mam_za_50_stanovitsya_vsyo_b } \\
\text { olshe } \\
\text { «Каждый человек смолоду должен иметь знания в области гигиены, вести здоро- } \\
\text { вый образ жизни. Тема для серьезного разговора»httрs://aif.ru/archive/1648367 }\end{array}$ \\
\hline $\begin{array}{l}\text { «Аргументы не- } \\
\text { дели», } \\
\text { https://argumenti.ru }\end{array}$ & $\begin{array}{l}\text { «Россияне признались, насколько сильно самоизоляция навредила отношениям в } \\
\text { семье» https://argumenti.ru/society/2020/07/677107 } \\
\text { «Депутат МГД Мельникова: Забота о здоровье должна стать ключевым критерием } \\
\text { новых программ для пожилых» https://argumenti.ru/society/2020/07/674505 }\end{array}$ \\
\hline $\begin{array}{c}\text { «Блокнот», } \\
\text { https://bloknot.ru }\end{array}$ & $\begin{array}{l}\text { «Дети в России стали чаще болеть, и причины - не секрет» } \\
\text { https://bloknot.ru/obshhestvo/deti-v-rossii-stali-chashhe-bolet-i-prichiny-ne-sekret- } \\
641260 . h t m l \\
\text { «Россияне массово покидают регионы в поисках работы» https://bloknot.ru/e- } \\
\text { konomika/rossiyane-massovo-pokidayut-regiony-v-poiskah-raboty-690931.html }\end{array}$ \\
\hline
\end{tabular}


Продолжение таблищь 1

\begin{tabular}{|c|c|}
\hline $\begin{array}{l}\text { Наименование } \\
\text { СМИ, интернет- } \\
\text { адрес }\end{array}$ & Выборочные материалы (статьи), интернет-адрес \\
\hline $\begin{array}{l}\text { «Ведомости», } \\
\text { https://www.vedom } \\
\quad \text { osti.ru }\end{array}$ & $\begin{array}{l}\text { «Спрос на гериатрические центры и жилье для старшего поколения растет» } \\
\text { https://www.vedomosti.ru/realty/articles/2020/04/08/827502-spros-na-meditsinskie- } \\
\text { tsentri-dlya-starshego-pokoleniya-rastet } \\
\text { «Вирус гонит pocсиян в деревню» } \\
\text { https://www.vedomosti.ru/economics/articles/2020/07/13/834494-virus-gonit-rossiyan-v- } \\
\text { derevnyu }\end{array}$ \\
\hline $\begin{array}{c}\langle\text { Газета.Ru», } \\
\text { http://www.gazeta.ru }\end{array}$ & $\begin{array}{l}\text { «Маткапитал на первенца: как власти поднимут рождаемость» } \\
\text { https://www.gazeta.ru/business/2020/01/15/12911456.shtml } \\
\text { «Где растет, где убывает: опубликована демография регионов РФ» } \\
\text { https://www.gazeta.ru/social/2020/04/20/13055515.shtml } \\
\text { «С ловно кролики»: как страны решают проблему демографии» } \\
\text { https://www.gazeta.ru/business/2020/01/12/12906620.shtml } \\
\text { «Демография под вопросом: как пандемия влияет на рождаемость» } \\
\text { https://www.gazeta.ru/business/2020/06/11/13114705.shtml }\end{array}$ \\
\hline $\begin{array}{l}\text { «Коммерсантъ», } \\
\text { https://www.komm } \\
\text { ersant.ru }\end{array}$ & $\begin{array}{l}\text { «Быстрый демографический переход: какие уроки может извлечь Россия из опыта } \\
\text { других стран» https://www.kommersant.ru/doc/4251975?query } \\
\text { «Женщины моложе } 35 \text { лет предпочитают карьеру личной жизни - опрос» } \\
\text { https://www.kommersant.ru/doc/4266667?query=\%D0\%BC\%D0\%BE\%D0\%BB\%D0\% } \\
\text { BE\%D0\%B4\%D0\%B0\%D1\%8F\%20\%D1\%81\%D0\%B5\%D0\%BC\%D1\%8C\%D1\%8F }\end{array}$ \\
\hline $\begin{array}{l}\text { «Московский } \\
\text { комсомолец», } \\
\text { https://www.mk.ru/ }\end{array}$ & $\begin{array}{l}\text { «Перенос маткапитала на первых детей ошибочен» } \\
\text { https://www.mk.ru/economics/2020/02/12/perenos-matkapitala-na-pervykh-detey- } \\
\text { oshibochen.html } \\
\text { «Экзамены онлайн. Что нужно учесть?» https://www.mk.ru/press- } \\
\text { center/2020/05/20/ekzameny-onlayn-chto-nuzhno-uchest.html }\end{array}$ \\
\hline $\begin{array}{c}\text { «РИА Новости», } \\
\text { http://ria.ru }\end{array}$ & $\begin{array}{l}\text { «Замглавы ВРНС рассказал, как решить проблему } \\
\text { https://ria.ru/20200217/1564857303.html } \\
\text { «Саратовский губернатор объяснил убыль населения снижением рождаемости» } \\
\text { https://ria.ru/20200206/1564370124.html }\end{array}$ \\
\hline $\begin{array}{c}\text { ТВЦ, } \\
\text { http://www.tvc.ru/ }\end{array}$ & $\begin{array}{l}\text { «Путин обратился с Посланием к Федеральному Собранию. Главное» } \\
\text { http://www.tvc.ru/news/show/id/176303 } \\
\text { «Маткапитал разрешено расходовать сразу после рождения ребенка» } \\
\text { https://www.tvc.ru/news/show/id/176751 } \\
\text { «Маткапитал предложили распространить на отцов-одиночек» } \\
\text { http://www.tvc.ru/news/show/id/178194 } \\
\text { «Путин назвал главный критерий успеха нацпроектов» } \\
\text { http://www.tvc.ru/news/show/id/178931 }\end{array}$ \\
\hline $\begin{array}{c}\text { «Forbes Poссия», } \\
\text { https://www.forbes.ru// }\end{array}$ & $\begin{array}{l}\text { Хрупкий институт. Нужны ли брак и семья «поколению снежинок» } \\
\text { https://www.forbes.ru/forbes-woman/379529-hrupkiy-institut-nuzhny-li-brak-i-semya- } \\
\text { pokoleniyu-snezhinok } \\
\text { Демография без географии. Почему пустеют регионы России } \\
\text { https://www.forbes.ru/obshchestvo/375283-demografiya-bez-geografii-pochemu- } \\
\text { pusteyut-regiony-rossii }\end{array}$ \\
\hline $\begin{array}{c}\text { «Meduza», } \\
\text { https://meduza.io/ }\end{array}$ & $\begin{array}{l}\text { «Естественная убыль России станет рекордной за } 11 \text { лет» } \\
\text { https://meduza.io/news/2019/12/13/estestvennaya-ubyl-naseleniya-rossii-stanet- } \\
\text { rekordnoy-za-11-let } \\
\text { «Как живут мигранты в России, чем обернулся для них коронавирус и какие сте- } \\
\text { реотипы на самом деле неверны» https://meduza.io/feature/2020/07/1 6/kak-zhivut- } \\
\text { migranty-v-rossii-chem-obernulsya-dlya-nih-koronavirus-i-kakie-stereotipy-na-samom- } \\
\text { dele-neverny }\end{array}$ \\
\hline
\end{tabular}




\begin{tabular}{|c|c|}
\hline $\begin{array}{l}\text { Наименован ие } \\
\text { СМИ, интернет- } \\
\text { адрес }\end{array}$ & Выборочные материалы (статьи), интернет-адрес \\
\hline $\begin{array}{c}\langle\mathrm{RT} », \\
\text { https://russian.rt.com/ }\end{array}$ & $\begin{array}{l}\text { «В Томской области рассказали о работе по повышению рождаемости» } \\
\text { https://russian.rt.com/russia/news/720517-region-rozhdaemost-podderzhka } \\
\text { «Эксперт оценил идею снижения первоначального взноса по ипотеке для молодых } \\
\text { семей» } \\
\text { https://russian.rt.com/russia/news/725954-ekspert-ipoteka-vznos-snizhenie } \\
\text { «Совфед одобрил закон о pacширении программы материнского капитала» } \\
\text { https://russian.rt.com/russia/news/722381-sovfed-zakon-materinskii-kapital } \\
\text { «В России в начале 2020 года сократилось число paзводов» } \\
\text { https://russian.rt.com/russia/news/745901-rossiya-sokraschenie-chisla-razvodov } \\
\text { «Ориентированность на пациента и обеспечение лекарствами: новый глава Мин- } \\
\text { здрава paсcказал о приоритетах ведомства» } \\
\text { https://russian.rt.com/russia/article/711051-minzdrav-perestanovki-medicina-rossiya- } \\
\text { lekarstva }\end{array}$ \\
\hline $\begin{array}{c}\text { «Вести.RU, } \\
\text { https://www.vesti.ru/ }\end{array}$ & $\begin{array}{l}\text { «Минтруда: население Забайкалья до } 2024 \text { года может уменьшиться на } 60 \text { тысяч» } \\
\text { https://www.vesti.ru/doc.html? id=3241962 } \\
\text { «Мишустин подписал постановление об ипотеке под 6,5\% годовых» } \\
\text { https://www.vesti.ru/doc.html?id=3259728 } \\
\text { «Росстат вновь констатировал сокращение населения страны» } \\
\text { https://www.vesti.ru/doc.html?id=3232938 } \\
\text { «Мужчины обращаются за амбулаторной медпомощью реже женщин, а умирают } \\
\text { чаще» } \\
\text { https://www.vesti.ru/doc.html? id=3246430 } \\
\text { «Рoccuяне нa3вали самую важную поправку в Конституцию» } \\
\text { https://www.vesti.ru/doc.html?id=3250730 }\end{array}$ \\
\hline $\begin{array}{l}\text { «Известия», } \\
\text { https://iz.ru/ }\end{array}$ & $\begin{array}{l}\text { Меньше, да не лучше: разрушит ли демографический кризис экономику } \\
\text { https://iz.ru/965206/dmitrii-migunov/menshe-da-ne-luchshe-razrushit-li- } \\
\text { demograficheskii-krizis-ekonomiku }\end{array}$ \\
\hline $\begin{array}{c}\text { «РБК Газета», } \\
\text { https://www.rbc.ru/ }\end{array}$ & $\begin{array}{l}\text { «Губернаторы оценили идею ввести «арктический гектар» } \\
\text { https://www.rbc.ru/business/16/07/2020/5f0c8f699a7947b5fab8dcc } 1 \\
\text { «Эксперты сравнили сокращение рабочего времени женщин и мужчин за пять лет» } \\
\text { https://www.rbc.ru/society/16/07/2020/5f0fd3039a79479073a98708 }\end{array}$ \\
\hline $\begin{array}{l}\text { «Российская Газе- } \\
\text { та (RG.RU)», } \\
\text { http://www.rg.ru }\end{array}$ & $\begin{array}{l}\text { «В парламенте и кабмине назвали меры по увеличению числа россиян» } \\
\text { https://rg.ru/2019/04/23/reg-szfo/v-parlamente-i-kabmine-nazvali-mery-po-uvelicheniiu- } \\
\text { chisla-rossiian.html } \\
\text { «Справиться с карантином пенсионерам помогает проект «Старшее поколение» } \\
\text { https://rg.ru/2020/06/24/reg-ufo/spravitsia-s-karantinom-pensioneram-pomogaet-proekt- } \\
\text { starshee-pokolenie.html }\end{array}$ \\
\hline $\begin{array}{l}\text { «АиФ Волго- } \\
\text { град», } \\
\text { http://www.vlg. } \\
\text { aif.ru }\end{array}$ & $\begin{array}{l}\text { «Минздрав РФ узнал про сокращение волгоградских роддомов» } \\
\text { https://vlg.aif.ru/politic/gover/384620 } \\
\text { «Защита детей. Как этому помогают нацпроекты?» } \\
\text { https://aif.ru/society/people/zashchita_detey_kak_etomu_pomogayut_nacproekty }\end{array}$ \\
\hline $\begin{array}{c}\text { «Блокнот Волго- } \\
\text { град», } \\
\text { https://bloknot- } \\
\text { volgo grad.ru }\end{array}$ & $\begin{array}{l}\text { «Волгоградская область вошла в двадцатку российских регионов по популярности } \\
\text { ЗОЖа» } \\
\text { https://bloknot-volgograd.ru/news/volgogradskaya-oblast-voshla-v-dvadtsatku-rossiysk- } \\
\text { 1022981?sphrase_id=1444585 } \\
\text { «Проверено на ceбe: похода к неврологу бояться не нужно» } \\
\text { https://bloknot-volgograd.ru/news/provereno-na-sebe-pokhoda-k-nevrologu-boyatsya- } \\
\text { ne-1008090?sphrase_id=1444585 } \\
\text { «Рождаемость продолжает стабильно падать в Волгоградской области: только в } \\
\text { Палласовке прирост населения» https://bloknot-volgograd.ru/news/rozhdaemost- } \\
\text { prodolzhaet-stabilno-padat-v-volgograd-1230856?sphrase id=1443971 }\end{array}$ \\
\hline
\end{tabular}


Продолжение таблищьы 1

\begin{tabular}{|c|c|}
\hline $\begin{array}{l}\text { Наименование } \\
\text { СМИ, интернет- } \\
\text { адрес }\end{array}$ & Выборочные материалы (статьи), интернет-адрес \\
\hline $\begin{array}{l}\text { «Вечерний Волго- } \\
\text { град», http://vv- } \\
\text { 34.ru }\end{array}$ & $\begin{array}{l}\text { «Город должен быть доступен для всех» http://vv-34.ru/gorod-dolzhen-byt-dostupen- } \\
\text { dlja-vseh.html } \\
\text { «Жильцам пострадавшего в Волгограде дома оказывается помощь» } \\
\text { http://vv-34.ru/zhilcam-postradavshego-v-volgograde-doma-okazyvaetsja-pomosch.html } \\
\text { «800 человек обратилось в Волгоградский центр содействия иммиграции за первые } \\
\text { дни работы» } \\
\text { http://vv-34.ru/800-chelovek-obratilos-v-volgogradskii-centr-sodeistvija-immigracii-za- } \\
\text { pervye-dni-raboty.html }\end{array}$ \\
\hline $\begin{array}{l}\text { «Волгоградская } \\
\text { правда», } \\
\text { http://vpravda.ru }\end{array}$ & $\begin{array}{l}\text { «Перспективы развития гериатрии обсудили в Волгограде» } \\
\text { https://vpravda.ru/obshchestvo/perspektivy-razvitiya-geriatrii-obsudili-v-volgograde- } \\
84670 /\end{array}$ \\
\hline $\begin{array}{l}\text { «Городские вести», } \\
\text { https://gorvesti.nu/ }\end{array}$ & $\begin{array}{l}\text { «В Волгограде «Справедливая Россия» предложила поправки в Конституцию» } \\
\text { https://gorvesti.ru/politics/v-volgograde-spravedlivaya-rossiya-predlozhila-popravki-v- } \\
\text { konstitutsiyu-83227.html } \\
\text { «Андрей Бочаров проинспектирует реализацию нацпроектов в Советском районе } \\
\text { Волгограда» } \\
\text { https:/gorvesti.ru/politics/andrey-bocharov-proinspektiruet-realizatsiyu-natsproektov-v- } \\
\text { sovetskom-rayone-volgograda-83000.html }\end{array}$ \\
\hline $\begin{array}{l}\text { «Деловой Волго- } \\
\text { град», } \\
\text { https://delosmi.ru }\end{array}$ & $\begin{array}{l}\text { «Банк в Волгограде выдал свыше } 200 \text { млн рублей на ипотеку по ставке 6,5\%» } \\
\text { https://delosmi.ru/2020/07/08/bank-v-volgo grade-vydal-svyshe-200-mln-rublej-na- } \\
\text { itoteku-po-stavke-6-5/ } \\
\text { «Брачный договор: мал овостребованная альтернатива» } \\
\text { https://delosmi.ru/2018/02/17/brachnyj-dogovor-malovostrebovannaya-al ternativa/ }\end{array}$ \\
\hline $\begin{array}{l}\text { «Комсомольская } \\
\text { правда в Волго- } \\
\text { граде», } \\
\text { https://www.volgo } \\
\text { grad.kp.ru } \\
\end{array}$ & $\begin{array}{l}\text { «По следам Послания Президента: что делают в Волгоградской области, чтобы } \\
\text { поднять рождаемость» } \\
\text { https://www.volgograd.kp.ru/daily/27078/4149963/ } \\
\text { «В Волгограде назвали семьи, которые поборются за звание лучших в стране» } \\
\text { https://www.volgograd.kp.ru/online/news/3881937/ }\end{array}$ \\
\hline $\begin{array}{l}\text { «Вести Волго- } \\
\text { град», } \\
\text { http://www.volgogr } \\
\text { ad-trv.ru/ }\end{array}$ & $\begin{array}{l}\text { «В Калаче-на-Дону развивают профессиональное обучение и патриотическое вос- } \\
\text { питание молодежи» http://www.volgograd-trv.ru/news.aspx?id=54864 } \\
\text { «ЭКО с становится } \quad \text { доступнеe } \quad \text { волгоградкам» } \quad \text { http://www.volgograd- } \\
\text { trv.ru/news.aspx?id=53030 }\end{array}$ \\
\hline $\begin{array}{l}\text { «Волгоград 24», } \\
\text { http://volgograd24.tv/ }\end{array}$ & $\begin{array}{l}\text { «Жизнь замечательных семей» } \\
\text { http://volgograd24.tv/programmy/37/ }\end{array}$ \\
\hline $\begin{array}{l}\text { Волжская правда, } \\
\text { https://gazeta- } \\
\text { vp.ru/ }\end{array}$ & $\begin{array}{l}\text { «В Волжском стартовало строительство детского сада по нацпроекту «Демогра- } \\
\text { фия» } \\
\text { https://gazeta-vp.ru/v-volzhskom-startovalo-stroitelstvo-detskogo-sada-po-naczproektu- } \\
\text { demografiya/ }\end{array}$ \\
\hline $\begin{array}{l}\text { «Высота 102» } \\
\text { https://v102.ru/ }\end{array}$ & $\begin{array}{l}\text { «В Волгоградской области на нацпроект «Демография» в } 2020 \text { году потратят более } \\
6 \text { миллиардов рублей» } \\
\text { https://v102.ru/news/86558.html }\end{array}$ \\
\hline $\begin{array}{c}\text { «Диалог», } \\
\text { https://dialog1918.ru/ }\end{array}$ & $\begin{array}{l}\text { «В Камышине готовят участки для передачи многодетным семьям» } \\
\text { https://dialog1918.ru/2020/01/24/v-kamyshine-gotovyat-uchastki-dlya-peredachi- } \\
\text { mnogodetnym-semyam/ } \\
\text { «Молодым мамам дадут возможность пройти профессиональное обучение» } \\
\text { https://dialog1918.ru/2020/01/09/molodym-mamam-dadut-vozmozhnost-projti- } \\
\text { professionalnoe-obuchenie/ }\end{array}$ \\
\hline $\begin{array}{l}\text { «Родной город», } \\
\text { http://rodgor- } \\
\text { vlg.ru/ }\end{array}$ & $\begin{array}{l}\text { «В Волгоградской области повышается рождаемость» } \\
\text { http://rodgor-vlg.ru/v-volgogradskoi-oblasti-povyshaetsja-rozhdaemost.html } \\
\text { «47 семейно-консультативных центров заработали в Волгоградской области» } \\
\text { http://rodgor-vlg.ru/47-semeino-konsultativnyh-centrov-zarabotali-v-volgogradskoi- } \\
\text { oblasti.html }\end{array}$ \\
\hline
\end{tabular}


Разработка инструментария для проведения контент-анализа федеральных и региональных СМИ в России

Окончание таблищьы 1

\begin{tabular}{|c|l|}
\hline $\begin{array}{c}\text { Наименование } \\
\text { СМИ, интернет- } \\
\text { адрес }\end{array}$ & \multicolumn{1}{|c|}{ Выборочные материалы (статьи), интернет-адрес } \\
\hline $\begin{array}{c}\text { «усть- } \\
\text { Медведицкая га- } \\
\text { зета», } \\
\text { http://umgazeta.ru/ }\end{array}$ & $\begin{array}{l}\text { «Продажа несовершеннолетним безалкогольных тонизирующих напитков будет } \\
\text { запрещена» } \\
\text { http://umgazeta.ru/vesti-poselenij/prodazha-nesovershennoletnim-bezalkogolnyh- } \\
\text { toniziruyushhih-napitkov-budet-zapreshhena/ } \\
\text { «3a любовь и верность: семь Boлгоградской области отмечены наградами» } \\
\text { http://umgazeta.ru/sobytie/za-lyubov-i-vernost-semi-volgogradskoj-oblasti-otmecheny- } \\
\text { nagradami/ }\end{array}$ \\
\hline
\end{tabular}

Генеральная совокупность состоит из статей, размещенных в таких средствах распространения информации, как электронные газеты, сайты. Если объем материалов, подвергающихся контент-аналитической обработке, не слишком большой и может быть легко обработан, то проводится сплошное обследование, в котором изучаются все элементы генеральной совокупности. При обработке больших массивов информации, где проведение сплошного обследования не представляется возможным, используется выборка материалов, репрезентативная по отношению к генеральной совокупности.

Для исследования отбираются СМИ общественно-политической направленности, а также популярные новостные издания, предназначенные для широкого круга читателей. Выбор таких изданий, занимающих неравное положение в информационном пространстве, обусловлен стремлением наиболее полно осветить поставленную проблему.

Отбор текстов производится по ключевым словам с помощью поисковых систем. Обязательным условием включения текста в массив, подлежащий анализу, является наличие демографического компонента. Единицами анализа являются понятия, которые характеризуют статьи, посвященные демографическим проблемам в РФ: поддержке семей при рождении детей, помощь старшему поколению и другие логически-связанные с присутствием проблем демографии в СМИ.

На четвертом этапе исследования определяется процедура обработки информации, полученной в ходе контент-анализа, устанавливаются формализованные бланки для ее подсчета, анализа и интерпретации. Единицы счета используются для регистрации регуляр- ности, с которой встречаются в тексте смысловые единицы, а также анализа физической протяженности текстов, числа знаков (букв), строк, абзацев. В качестве единиц счета можно использовать простое количество упоминаний той или иной выделенной темы, а за единицу измерения в итоге необходимо принять процентное отношение числа упоминаний темы или категории к общему количеству исследованных статей. Единицы контекста будут представлены предложениями, абзацами, статьями, содержащими в себе единицы анализа и представляющими собой ту или иную позицию, будь то общественное мнение, мнение редакции, или мнение автора публикации.

В данной связи смысловыми единицами контент-анализа в рамках заявленной темы могут быть: аборт; акиент на многодетных и малоимущих семьях; алкоголь; благополучие семьи; брак; брачность и разводимость; бюджет семьи; взаимоотношения в семье; Владимир Путин; внуки; возраст вступления в брак резко вырос; воспитание детей; воспитание ребенка; вредные привычки; выполнение национальной задачи; демографическая ситуачия; демографическая яма; демографические проблемы; демография; деторождение; детские врачи; долголетие; доход семьи; желание иметь детей; желание иметь ребенка; желание отложить рождение детей; желание отложить рождение ребенка; жилищные условия семьи; здоровый образ жизни; здоровье; ипотека; качество жизни; количество детей в семье; количество родов сократилось; курение; материальный достаток семьи; материнский капитал; многодетные семьи; многопоколенная семья; молодые супруги; научно-учебная 
лаборатория сочииально-демографической политики; национальные проекты; недостаток мест; неуверенность в своем будущем; новый детский сад; нужна любая помощь; образование детей; отсутствие вредных привычек в семье; очередь в ясли; повышение рождаемости; политическая демография; помощь семьям; пособие на ребенка; предки; проблемы в семье; продолжительность жизни человека; развитие детей; ребенок; репродуктивные технологии; репродуктивный потенциал; родственники; рождаемость; рождение детей; Россию ожидает демографический коллапс; рост религиозности и веры; семейная жизнь; семейные традииии; семейные ценности; семья; смертность; состояние здоровья; сочиальная помощь семьям; социологи бьют тревогу; стратегия народосбережения; суррогатное материнство; трудности в семье; убыль населения; уровень института семьи; условия жизни семьи; уход матери с работы; эпидемиологическая ситуация.

В качестве категорий могут выступать основные понятия или базовые характеристики объекта исследования и соответствующие им признаки, эмпирические референты.

Приведем пример составления категориальной сетки контент-анализа, перечня категорий и выделения параметров на основе анализа эмпирических объектов исследования (табл. 2).

На пятом этапе происходит составление классификаций, типологий признаков объекта и строгое описание процедуры фиксации единиц счета в тексте и их отнесения к соответствующим категориям и разделам.

Таблица 2

\section{Пример составления категориальной сетки контент-анализа, перечня категорий и выделения параметров на основе анализа эмпирических объектов исследования}

\begin{tabular}{|c|c|c|c|}
\hline $\begin{array}{l}\text { № } \\
\Pi / \Pi\end{array}$ & Категории & Код & Параметры \\
\hline \multirow[t]{4}{*}{1.} & \multirow[t]{4}{*}{ Помощь семьям } & 1.1 & Материнский капитал \\
\hline & & 1.2 & Пособия семьям на ребенка до 7 лет \\
\hline & & 1.3 & Выплаты на первого и второго ребенка до 3 лет \\
\hline & & 1.4 & Бесплатное горячее питание для школьников \\
\hline \multirow[t]{7}{*}{2.} & \multirow{7}{*}{$\begin{array}{l}\text { Пути решения де- } \\
\text { мографической } \\
\text { проблемы }\end{array}$} & 2.1 & Значительное сокращение количества абортов \\
\hline & & 2.2 & Стратегия народосбережения России \\
\hline & & 2.3 & Дать миллион на третьего ребенка \\
\hline & & 2.4 & Проиндексировать маткапитал за все годы \\
\hline & & 2.5 & Доступ к разным сервисам по уходу за ребенком \\
\hline & & 2.6 & Снижать расходы на детей \\
\hline & & 2.7 & Рост религиозности и веры \\
\hline \multirow[t]{5}{*}{3.} & \multirow{5}{*}{$\begin{array}{l}\text { Причины снижения } \\
\text { деторождаемости }\end{array}$} & 3.1 & Изменение отношения в обществе к детям \\
\hline & & 3.2 & Молодые ребята не общаются с девушками \\
\hline & & 3.3 & Неуверенность в своем будущем \\
\hline & & 3.4 & Женщины поздно решаются завести ребенка \\
\hline & & 3.5 & Повышение роли женщины в обществе \\
\hline \multirow[t]{4}{*}{4.} & \multirow{4}{*}{$\begin{array}{l}\text { Причины демогра- } \\
\text { фического кризиса }\end{array}$} & 4.1 & «Демографическая яма» \\
\hline & & 4.2 & Высокая смертность мужчин \\
\hline & & 4.3 & Низкий уровень здоровья населения \\
\hline & & 4.4 & Употребление табака и алкоголя населением \\
\hline \multirow[t]{4}{*}{5.} & \multirow[t]{4}{*}{ Формат статьи } & 5.1 & Рекомендация \\
\hline & & 5.2 & Реальная ситуация \\
\hline & & 5.3 & Дискуссия с влиятельным должностным лицом \\
\hline & & 5.4 & Статистические данные \\
\hline \multirow[t]{5}{*}{6.} & \multirow{5}{*}{$\begin{array}{l}\text { Персонажи, о кото- } \\
\text { рых в статье идет } \\
\text { речь }\end{array}$} & 6.1 & Молодая семья с детьми \\
\hline & & 6.2 & Молодая семья без детей \\
\hline & & 6.3 & Зрелая семья \\
\hline & & 6.4 & Люди, не состоящие в официальном браке \\
\hline & & 6.5 & Люди, не состоящие в отношениях (не связанные персонажи) \\
\hline
\end{tabular}


Разработка инструментария для проведения контент-анализа федеральных и региональных СМИ в России

Продолжение таблиџы 2

\begin{tabular}{|c|c|c|c|}
\hline $\begin{array}{l}\text { № } \\
\Pi / \Pi \\
\end{array}$ & Категории & Код & Параметры \\
\hline \multirow[t]{6}{*}{7.} & \multirow[t]{6}{*}{ Их социальная роль } & 7.1 & Супруги \\
\hline & & 7.2 & Детско-родительские отношения \\
\hline & & 7.3 & Сожители \\
\hline & & 7.4 & Родственники \\
\hline & & 7.5 & Знакомые люди по тем или иным обстоятельствам \\
\hline & & 7.6 & Не знакомые лично люди \\
\hline \multirow[t]{9}{*}{8.} & \multirow[t]{9}{*}{ Тематика статьи } & 8.1 & Семейные отношения \\
\hline & & 8.2 & Добрачные отношения \\
\hline & & 8.3 & Здоровье в семье \\
\hline & & 8.4 & Бюджет семьи \\
\hline & & 8.5 & Семьи, нуждающиеся в социальной помощи \\
\hline & & 8.6 & Образование детей \\
\hline & & 8.7 & Продолжительность жизни \\
\hline & & 8.8 & Проблемы в семье \\
\hline & & 8.9 & Ипотека для семьи \\
\hline \multirow[t]{3}{*}{9.} & \multirow{3}{*}{$\begin{array}{l}\text { Продолжитель- } \\
\text { ность жизни насе- } \\
\text { ления }\end{array}$} & 9.1 & Растет \\
\hline & & 9.2 & Стабильна \\
\hline & & 9.3 & Уменьшается \\
\hline \multirow[t]{3}{*}{10.} & \multirow{3}{*}{$\begin{array}{l}\text { Качество жизни } \\
\text { семей в РФ }\end{array}$} & 10.1 & Ухудшается \\
\hline & & 10.2 & Стабильно \\
\hline & & 10.3 & Улучшается \\
\hline \multirow[t]{5}{*}{11.} & \multirow{5}{*}{$\begin{array}{l}\text { Финансовая под- } \\
\text { держка семей при } \\
\text { рождении детей }\end{array}$} & 11.1 & Достаточна \\
\hline & & 11.2 & Недостаточна \\
\hline & & 11.3 & Рождение детей \\
\hline & & 11.4 & Образование детей \\
\hline & & 11.5 & Материальный достаток семьи \\
\hline \multirow[t]{4}{*}{12.} & \multirow[t]{4}{*}{ Старшее поколение } & 12.1 & Продолжительность жизни человека \\
\hline & & 12.2 & Активное долголетие \\
\hline & & 12.3 & Забота о старшем поколении \\
\hline & & 12.4 & Семейные традиции \\
\hline \multirow[t]{4}{*}{13.} & \multirow{4}{*}{$\begin{array}{l}\text { Социальный фак- } \\
\text { тор }\end{array}$} & 13.1 & Количество разводов \\
\hline & & 13.2 & Количество браков \\
\hline & & 13.3 & Семейные ценности \\
\hline & & 13.4 & Миграция / иммиграция \\
\hline \multirow[t]{4}{*}{14.} & \multirow{4}{*}{$\begin{array}{l}\text { Экономический } \\
\text { фактор }\end{array}$} & 14.1 & Социальные выплаты \\
\hline & & 14.2 & Материнский капитал \\
\hline & & 14.3 & Безработица \\
\hline & & 14.4 & Миграция / иммиграция \\
\hline \multirow[t]{4}{*}{15.} & \multirow{4}{*}{$\begin{array}{l}\text { Медицинский фак- } \\
\text { тор }\end{array}$} & 15.1 & Смертность \\
\hline & & 15.2 & Рождаемость \\
\hline & & 15.3 & Репродуктивное здоровье \\
\hline & & 15.4 & Доступность и качество медицины \\
\hline 16. & Инфраструктурный & 16.1 & Количество перинатальных центров \\
\hline & фактор & 16.2 & Детские сады \\
\hline & & 16.3 & Школы \\
\hline 17. & Миграция & 17.1 & Временная миграция \\
\hline & & 17.2 & Постоянная миграция \\
\hline & & 17.3 & Миграция единожды \\
\hline & & 17.4 & Миграция повторная \\
\hline 18. & Дети & 18.1 & Менее 3-х детей \\
\hline & & 18.2 & Более 3-х детей \\
\hline & & 18.3 & Нет детей \\
\hline & & 18.4 & Против детей \\
\hline 19. & Достаток & 19.1 & На все хватает \\
\hline & & 19.2 & Средний заработок \\
\hline & & 19.3 & Ниже среднего \\
\hline & & 19.4 & Крайне мал \\
\hline
\end{tabular}


Продолжение таблищы 2

\begin{tabular}{|c|c|c|c|}
\hline $\begin{array}{l}\text { № } \\
\Pi / \Pi\end{array}$ & Категории & Код & Параметры \\
\hline \multirow[t]{4}{*}{20.} & \multirow[t]{4}{*}{ ЗОЖ } & 20.1 & Соблюдается постоянно \\
\hline & & 20.2 & Соблюдается частично \\
\hline & & 20.3 & Не соблюдается \\
\hline & & 20.4 & Имеет место отказ от вредных привычек \\
\hline \multirow[t]{7}{*}{21.} & \multirow[t]{7}{*}{ Брак } & 21.1 & Женат / замужем \\
\hline & & 21.2 & Разведен / разведена \\
\hline & & 21.3 & Не замужем / не женат \\
\hline & & 21.4 & Вдовец / вдова \\
\hline & & 21.5 & Межнациональный брак \\
\hline & & 21.6 & Однополые отношения \\
\hline & & 21.7 & Отрицательное отношение к бракам \\
\hline \multirow[t]{5}{*}{22.} & \multirow[t]{5}{*}{ Аборт } & 22.1 & «За» аборты \\
\hline & & 22.2 & Делали аборт единожды \\
\hline & & 22.3 & Делали аборт несколько раз \\
\hline & & 22.4 & Против абортов \\
\hline & & 22.5 & Не делали аборт \\
\hline \multirow[t]{10}{*}{23.} & \multirow[t]{10}{*}{ Образование } & 23.1 & Среднее общее образование \\
\hline & & 23.2 & Основное (полное) общее образование \\
\hline & & 23.3 & Среднее профессиональное образование \\
\hline & & 23.4 & Высшее образование - бакалавриат, специалитет \\
\hline & & 23.5 & Высш ее образование - магистратура \\
\hline & & 23.6 & Высшее образование - подготовка кадров высшей квалификации \\
\hline & & 23.7 & Повышение качества образования \\
\hline & & 23.8 & Понижение качества образования \\
\hline & & 23.9 & Бесплатное образование \\
\hline & & 23.10 & Платное образование \\
\hline \multirow[t]{4}{*}{24.} & \multirow{4}{*}{$\begin{array}{l}\text { Формат новостного } \\
\text { блока }\end{array}$} & 24.1 & Информационный \\
\hline & & 24.2 & Статистический \\
\hline & & 24.3 & Предупреждающий \\
\hline & & 24.4 & Познавательный \\
\hline \multirow[t]{6}{*}{25.} & \multirow[t]{6}{*}{ Действующие лица } & 25.1 & Эксперты \\
\hline & & 25.2 & Врачи \\
\hline & & 25.3 & Социологи \\
\hline & & 25.4 & Корреспонденты \\
\hline & & 25.5 & Президент \\
\hline & & 25.6 & Государство \\
\hline \multirow[t]{3}{*}{26.} & \multirow[t]{3}{*}{ Угрозы } & 26.1 & Присутствуют \\
\hline & & 26.2 & Частично \\
\hline & & 26.3 & Отсутствуют \\
\hline \multirow[t]{5}{*}{27.} & \multirow{5}{*}{$\begin{array}{l}\text { Характер демогра- } \\
\text { фической ситуации }\end{array}$} & 27.1 & Положительная \\
\hline & & 27.2 & Нейтральная \\
\hline & & 27.3 & Крайне неблагоприятная \\
\hline & & 27.4 & Кризис \\
\hline & & 27.5 & Катастрофа \\
\hline \multirow[t]{3}{*}{28.} & \multirow{3}{*}{$\begin{array}{l}\text { Отношение к ме- } \\
\text { рам государствен- } \\
\text { ного стимулирова- } \\
\text { ния рождаемости }\end{array}$} & 28.1 & Позитивное \\
\hline & & 28.2 & Нейтральное \\
\hline & & 28.3 & Негативное \\
\hline \multirow[t]{3}{*}{29.} & \multirow{3}{*}{$\begin{array}{l}\text { Отношение к ми- } \\
\text { грации }\end{array}$} & 29.1 & Позитивное \\
\hline & & 29.2 & Нейтральное \\
\hline & & 29.3 & Негативное \\
\hline \multirow[t]{2}{*}{30.} & Высказывания из- & 30.1 & Фамилия, имя \\
\hline & $\begin{array}{l}\text { вестных личностей } \\
\text { о проблемах демо- } \\
\text { графии в РФ }\end{array}$ & 30.2 & Сфера деятельности личности \\
\hline
\end{tabular}




\begin{tabular}{|c|c|c|c|}
\hline $\begin{array}{l}\text { № } \\
\Pi / \Pi \\
\end{array}$ & Категории & Код & Параметры \\
\hline \multirow[t]{4}{*}{31.} & \multirow{4}{*}{$\begin{array}{l}\text { Наличие статисти- } \\
\text { ческой информа- } \\
\text { ции }\end{array}$} & 31.1 & Содержит информацию \\
\hline & & 31.2 & Имеется ссылка на источник \\
\hline & & 31.3 & Ссылка на источник отсутствует \\
\hline & & 31.4 & Источник четко не указан \\
\hline \multirow[t]{7}{*}{32.} & \multirow{7}{*}{$\begin{array}{l}\text { Направления, свя- } \\
\text { занные с финанси- } \\
\text { рованием демогра- } \\
\text { фической политики }\end{array}$} & 32.1 & Материнский капитал \\
\hline & & 32.2 & Преимущества многодетных и малоимущих семей \\
\hline & & 32.3 & Доход семьи \\
\hline & & 32.4 & Бюджет семьи \\
\hline & & 32.5 & Пособие на ребенка \\
\hline & & 32.6 & Ипотека \\
\hline & & 32.7 & Содействие трудоустройству матери \\
\hline \multirow[t]{3}{*}{33.} & \multirow{3}{*}{$\begin{array}{l}\text { Направления, свя- } \\
\text { занные с развитием } \\
\text { социокультурной } \\
\text { сферы и инфра- } \\
\text { структуры регио- } \\
\text { нов }\end{array}$} & 33.1 & Новый детский сад \\
\hline & & 33.2 & Недостаток мест в школах \\
\hline & & 33.3 & Очередь в ясли \\
\hline \multirow[t]{6}{*}{34.} & \multirow{6}{*}{$\begin{array}{l}\text { Направления, свя- } \\
\text { занные с развитием } \\
\text { медицинской сфе- } \\
\text { ры в регионах }\end{array}$} & 34.1 & Эпидемиологическая ситуация \\
\hline & & 34.2 & Детские врачи \\
\hline & & 34.3 & Суррогатное материнство \\
\hline & & 34.4 & Репродуктивные технологии \\
\hline & & 34.5 & Онкологические заболевания \\
\hline & & 34.6 & Здоровье \\
\hline \multirow[t]{6}{*}{35.} & \multirow{6}{*}{$\begin{array}{l}\text { Демографические } \\
\text { события }\end{array}$} & 35.1 & Национальный проект «Демография» \\
\hline & & 35.2 & «Детский стандарт» \\
\hline & & 35.3 & Социологи бьют тревогу \\
\hline & & 35.4 & Количество родов сократилось \\
\hline & & 35.5 & Девятое место в мире по количеству населения \\
\hline & & 35.6 & Научно-учебная лаборатория социально-демографической политики \\
\hline \multirow[t]{4}{*}{36.} & \multirow{4}{*}{$\begin{array}{l}\text { Семейные ценно- } \\
\text { сти }\end{array}$} & 36.1 & Возраст вступления в брак резко вырос \\
\hline & & 36.2 & Желание иметь ребенка \\
\hline & & 36.3 & Семья \\
\hline & & 36.4 & Желание отложить рождение ребенка \\
\hline \multirow[t]{2}{*}{37.} & \multirow[t]{2}{*}{ Характер статей } & 37.1 & $\begin{array}{l}\text { Статья освещает демографическую ситуацию с положительной сторо- } \\
\text { ны }\end{array}$ \\
\hline & & 37.2 & Статья освещает демографическую ситуацию с отрицательной стороны \\
\hline \multirow[t]{3}{*}{38.} & \multirow[t]{3}{*}{ Политические лица } & 38.1 & В статье упоминается политический лидер \\
\hline & & 38.2 & В статье упоминаются другие представители власти \\
\hline & & 38.3 & В статье не упоминаются лица, имеющие политический вес \\
\hline \multirow[t]{3}{*}{39.} & \multirow{3}{*}{$\begin{array}{l}\text { Эмоциональная на- } \\
\text { груженность заго- } \\
\text { ловка и подзаго- } \\
\text { ловка }\end{array}$} & 39.1 & Количество позитивно нагруженных эмоциональных слов \\
\hline & & 39.2 & Количество негативно нагруженных эмоциональных слов \\
\hline & & 39.3 & Количество нейтральных слов \\
\hline
\end{tabular}

Наиболее часто встречаемые слова в приведенных выше статьях: демографический кризис, убыль населения, рождаемость, материнский капитал, социальная помощь, продолжительность жизни человека, материальный достаток семьи, состояние здоровья, аборт, семья, ребенок.

Приведем пример расшифровки кодировочных таблиц для категории «Причины демографических проблем». Речь идет о причинах убыли населения в РФ. Рассматриваются восемь параметров:

1. Высокий уровень тревоги у людей и неуверенность в своем будущем:

«Люди строят короткий план выживания, как тут можно думать о ребенке? Им хочется дать хотя бы одному ребенку все необходимое. Есть закономерность, что удовлетво- 
ренность браком заметно падает после рождения ребенка. Семья становится беднее, а жизнь женщины превращается в ад».

2. Изменение отношения в обществе $\kappa$ детям: люди хотят «жить для себя».

3. Факторы экономического порядка: в кризисы люди меньше рожают детей изза неуверенности в завтрашнем дне, страха потерять источник дохода, проблем жилищного характера и т.д.

4. В 1990-х годах целая серия кризисов, рост безработицы, резкое сокращение государственной поддержки семей, разрушение социальной инфраструктуры (закрытие детских учреждений, поликлиник, больниц и проч.) привели к так называемой «демографической яме» - резкому сокращению численности населения - которая также наложилась на так называемое «демографическое эхо войныl» (катастрофические последствия депопуляции в результате Великой Отечественной войны).

5. Низкая продолжительность жизни: алкоголизм, недоступность медицинских услуг вследствие их растущей стоимости и сокращения бесплатной медицины.

6. Женшины в России слишком поздно решаются завести первого ребенка, а это означает, что в семье будет в лучшем случае не более 1-2 детей, что не сможет обеспечить прирост населения.

7. Повышение роли женшины в обществе, желание сделать карьеру и проч. все это снижает стремление обзаводиться семьей и рожать детей, или способствует откладыванию этого.

8. Государственная система детского образования и здравоохранения замещается частными учреждениями: в стране фактически уничтожена система государственной поддержки материнства и детства и только сейчас государство и общественность стали обращать на нее внимание, акцентируя внимание на ее роли в обеспечении национальной безопасности.

Категория «Способы решения демографических проблем» предполагает целенаправленную деятельность государственных органов и иных социальных институтов в сфере регулирования воспроизводства населения, призванную сохранить или изменить тенденции динамики его численности и структуры. Рассматриваются параметры:

1. «Значительное сокращение количества абортов легко решит демографические проблемы в стране», - заявил Патриарх Московский и всея Руси Кирилл 28 января 2020 г. в ходе выступления на Рождественских парламентских встречах в СФ ФС РФ.

2. В.В. Путин в своем Послании Федеральному Собранию Российской Федерации в 2020 году отметил, что Россия должна играть ведущую роль в поддержании миропорядка, для того чтобы исправить демографическую ситуацию в стране.

3. Планирование экономики на основе тенденций демографии и демографической политики, поддержание политики сохранения и развития человеческого капитала, развития семейных ценностей, охраны материнства, отцовства, детства, поддержки активного долголетия, содействия развитию программ и проектов в области миграции населения, трудоустройства и занятости.

4. «Если мы не можем решить быстро проблему низких доходов, то единственный выход - сокращение расходов семьи на содержание ребенка... Чтобы в детских садах, школах и институтах было по максимуму все бесплатным для родителей», - считает Александр Сафонов.

5. «Я предлагаю дать миллион на третьего ребенка! Миллион - это стимул! Влияние маткапитала на рождаемость первенцев я оцениваю в 10 раз меньше. Еще бы я предложил проиндексировать маткапитал за все годы, и отдать все долги за те годы, когда он не индексировался», - полагает независимый демограф-эксперт Алексей Ракша.

6. «Женщины должны иметь возможность совмещать работу и семейные обязанности, должен быть доступ к разным сервисам по уходу за ребенком, в том числе, например, инвестировать больше средств в систему яслей, а еще так воспитывать детей, чтобы они были приспособлены к реальной взрослой жизни, учить их принимать решения», - считает доцент кафедры демографии НИУ ВШЭ Владимир Козлов.

7. Создание системы здоровьесбережения населения России. 
Разработка инструментария для проведения контент-анализа федеральных и региональных СМИ в России

Категория «Формат статьи». В источниках контент-аналитического исследования рассматриваются многообразные жанры статей. Рассматриваются 4 параметра.

1. Рекомендация. В статье рассматриваются рекомендательные меры по вопросу, соответствующему тематике исследования.

2. Реальная ситуащия. Статья содержит повествовательную информацию о ситуации, произошедшей с реальными людьми.

3. Дискуссия с влиятельным должностным лицом. В статье представлено интервью или его фрагменты на тему, соответствующую тематике исследования.

4. Статистические данные. Статья содержит статистические данные на интересующую исследователя тематику.

Категория «Персонажи, о которых в статье идет речь»:

1. Молодая семья с детьми. Изучаемый источник содержит информационные данные о семейной паре с детьми.

2. Молодая семья без детей. Информация в рассматриваемой статье повествует о молодой семье, не имеющих детей.

3. Зрелая семья. Речь в статье идет о не молодой семье, состоящей из двух и более поколений.

4. Люди, не состоящие в официальном браке. В статье содержится информация о людях, не связанных узами официального брака.

5. Люди, не состоящие в отношениях (не связанные персонажи). Речь идет о людях, не связанных кровным родством или узами брака.

Категория «Социальная роль»:

1. Супруги. В источниках речь идет о супружеских отношениях, их особенностях, влияющих на них факторах.

2. Детско-родительские отношения. Подверженные анализу статьи повествуют о детско-родительских отношениях.

3. Сожители. Содержится информация о людях, не состоящих в браке.

4. Знакомые люди по тем или иным обстоятельствам. Представленная информация о не состоящих в отношениях людях, знающих друг друга.

5. Не знакомые лично люди. Персонажи статьи не знакомы.

\section{Категория «Тематика статьи»:}

1. Семейные отношения. Статья полностью или частично посвящена семейным отношениям.

2. Добрачные отношения. В статье рассматриваются добрачные отношения.

3. Здоровье в семье. Исследуемый источник содержит данные о здоровье членов семьи.

4. Бюджет семьи. В источнике, подвергаемом контент-анализу, содержатся данные о бюджете семьи, его источниках, доходах и расходах.

5. Семьи, нуждаюшиеся в сочиальной помощи. Источник свидетельствует о мерах социальной поддержки семей, нуждающихся в ней, а также о связанных с ней явлениях, событиях и факторах.

6. Образование детей. В статье представлена информация об образовании детей, его особенностях.

7. Продолжительность жизни. Исследуемый источник посвящен продолжительности жизни, условиям и факторам, способствующим ее увеличению, а также статистическим данным по данной тематике.

8. Проблемы в семье. В статье рассматриваются многообразные проблемы, с которыми сталкивается или может столкнуться семья.

9. Ипотека для семьи. Исследуемая информация содержит данные об ипотечном займе, его преимуществах / недостатках, особенностях, условиях получения.

Использование контент-анализа как метода сбора социологической информации предполагает понимание того, какие стороны социальной реальности возможно объективно изучить при помощи данного метода, а какие - нет. Демография, демографические процессы, тенденции, политика в области демографии могут быть изучены с помощью метода контент-анализа по предложенному нами инструментарию.

Метод контент-анализа позволяет обеспечить высокую степень надежности полученных данных (возможность их перепроверки); исключить влияние исследователя на изучаемый объект (не включенность, «ненавязчивость» метода, предполагающая элиминирование «эффекта присутствия»); дает возможность точной 
и беспристрастной регистрации внешне неразличимых показателей в объемных массивах эмпирических данных. Анализ массивов публикаций в федеральных и региональных СМИ позволит представить общее видение проблем, тенденций и противоречий в области демографии и демографической политики как на уровне федерации, так и на региональном уровне, в субъектах Российской Федерации, сформулировать запросы общества к управленческим решениям в этой сфере, оценить эффективность предпринимаемых властями мер.

\section{ПРИМЕЧАНИЕ}

${ }^{1}$ Статья подготовлена при финансовой поддержке РНФ в рамках научного проекта № 20-1800256 «Демографическое поведение населения в контексте национальной безопасности России».

The article was prepared with the financial support of the Russian Science Foundation, RSF, in the framework of the scientific project no. 20-18-00256 "Demographic behavior of the population in the context of Russia's national security".

\section{СПИСОК ЛИТЕРАТУРЫ}

Бизнес. Толковый словарь 1998 - Бизнес. Толковый словарь. М.: ИНФРА-М; Весь Мир, 1998.

Большая актуальная политическая энциклопедия 2009 - Большая актуальная политическая энциклопедия. М.: Эксмо, 2009.

Вакуленко 2016 - Вакуленко Ю. Р. Специфика освещения проблемы демографии в печатных СМИ [Огарев-online. 2016. № 12] // http:// journal.mrsu.ru/arts/specifika-osveshheniyaproblemy-demografii-v-pechatnyx-smi (дата обращения: 12.02.2020).

Паспорт национального проекта «Демография» web - Паспорт Национального проекта «Демография»// https://rosmintrud.ru/ministry/programms/ demography (дата обращения 12.02.2020).

Троцук 2017 - Троцук И.В. О метатеоретизировании в области анализа текстовых данных // Социологические исследования. 2017. № 9. C. 12-21. DOI: https://doi.org/10.7868/ S0132162517090033.

Об утверждении Концепции... web - Об утверждении Концепции демографической политики Российской Федерации на период до 2025 года: Указ Президента РФ от 09.10.2007 № 1351 (ред. от 01.07.2014). Доступ из справ.-правовой системы «КонсультантПлюс».
Allman 2019 - Allman D. Social Inclusion from on High: A Poststructural Comparative Content Analysis of Drug Policy Texts from Canada and Scotland // The International Journal on Drug Policy. 2019. № 71. P. 19-28. DOI: https://doi.org/ 10.1016/j.drugpo.2019.03.027.

Cluley 2016 - Cluley $R$. The Depiction of Marketing and Marketers in the News Media // European Journal of Marketing. 2016. Vol. 50, № 5-6. P. 752-769.

Ernst 2009 - Ernst S. Using Qualitative Content Analysis of Popular Literature for Uncovering Long-Term Social Processes: The Case of Gender Relations in Germany [Historical Social Research / Historische Sozialforschung. 2009. Vol. 34. no.1 (127)] // https://www.jstor.org/ stable/20762344.

Zablocki 2013 - Zablocki G. The State of Rural Sociology as Presented in Four Periodicals Rural Sociology, Sociologia Ruralis, Journal of Rural Studies, Eastern European Countryside // Sciendo, Eastern European Countryside. 2013. № 19. P. 9-27.

\section{REFERENCES}

Business. Explanatory Dictionary, 1998. Moscow, INFRA-M Publ., Ves Mir Publ.

Great Topical Political Encyclopedia, 2009. Moscow, Eksmo Publ.

Vakulenko Y. R., 2016. Specificity of Coverage of the Problem of Demography in Print Media. Ogarevonline, no. 12. URL: http://journal.mrsu.ru/arts/ specifika-osveshheniya-problemy-demografiiv-pechatnyx-smi (accessed 12 February 2020).

Passport of the National Project "Demography". URL: https://rosmintrud.ru/ministry/programms/ demography (accessed 12 February 2020).

Trotsuk I.V., 2017. Metatheorizing in the Sociological Study of Textual Data. Sotsiologicheskie issledovaniya [Sociological Studies], no. 9, pp. 12-21. DOI: https://doi.org/10.7868/ S0132162517090033.

On Approval of the Concept of the Demographic Policy of the Russian Federation for the Period Up to 2025. Decree of the President of the Russian Federation Dated 09.10.2007 no. 1351 (ed.from 01.07.2014). Access from Reference Legal System 'KonsultantPlus'.

Allman D., 2019. Social Inclusion from on High: A Poststructural Comparative Content Analysis of Drug Policy Texts from Canada and Scotland. The International Journal on Drug Policy, no. 71, pp. 19-28. DOI: https://doi.org/10.1016/ j.drugpo.2019.03.027. 
Cluley, R., 2016. The Depiction of Marketing and Marketers in the News Media. European Journal of Marketing, vol. 50, no. 5-6, pp. 752-769.

Ernst S., 2009. Using Qualitative Content Analysis of Popular Literature for Uncovering Long-Term Social Processes: The Case of Gender Relations in Germany. Historical Social Research/Historische
Sozialforschung, vol. 34, no. 1 (127), pp. 252-269. URL: https://www.jstor.org/stable/20762344.

Zablocki G., 2013. The State of Rural Sociology as Presented in Four Periodicals - Rural Sociology, Sociologia Ruralis, Journal of Rural Studies, Eastern European Countryside. Sciendo, Eastern European Countryside, vol. 19, pp. 9-27.

\section{Information About the Authors}

Tamara K. Rostovskaya, Doctor of Sciences (Sociology), Professor, Honorary Employee of the Sphere of Youth Policy of the Russian Federation, Deputy Director, Institute for Demographic Research - Branch of the Federal Center of Theoretical and Applied Sociology of the Russian Academy of Sciences, Fotievoy St, 6, Bld. 1, 119333 Moscow, Russian Federation, rostovskaya.tamara@mail.ru, https://orcid.org/0000-0002-1629-7780

Ekaterina N. Vasilieva, Doctor of Sciences (Sociology), Associate Professor, Director, Institute of History, International Relations and Social Technologies, Volgograd State University, Prosp. Universitetsky, 100, 400062 Volgograd, Russian Federation; Leading Researcher, Institute for Demographic Research - Branch of the Federal Center of Theoretical and Applied Sociology of the Russian Academy of Sciences, Fotievoy St, 6, Bld. 1, 119333 Moscow, Russian Federation, vasilevaen@volsu.ru, https://orcid.org/0000-0002-0460-5539

Ekaterina A. Knyazkova, Candidate of Sciences (Politics), Senior Researcher, Department of Family and Family-Demographic Policy, Institute for Demographic Research - Branch of the Federal Center of Theoretical and Applied Sociology of the Russian Academy of Sciences, Fotievoy St, 6, Bld. 1, 119333 Moscow, Russian Federation; Associate Professor, Faculty of Sociology, Russian State University for the Humanities, Miusskaya Sq., 6, 125993 Moscow, Russian Federation, eapavlova@bk.ru, https://orcid.org/0000-0002-4032-1656

Elena O. Danilova, Candidate of Sciences (Sociology), Senior Lecturer, Department of Sociology and Social Technologies, Volgograd State University, Prosp. Universitetsky, 100, 400062 Volgograd, Russian Federation, danilovaelena@volsu.ru, https://orcid.org/0000-0002-2859-2226

\section{Информация об авторах}

Тамара Керимовна Ростовская, доктор социологических наук, профессор, почетный работник сферы молодежной политики Российской Федерации, заместитель директора Института демографических исследований ФНИСЦ РАН, ул. Фотиевой, 6, к. 1, 119333 г. Москва, Российская Федерация, rostovskaya.tamara@mail.ru,https://orcid.org/0000-0002-1629-7780

Екатерина Николаевна Васильева, доктор социологических наук, доцент, директор института истории, международных отношений и социальных технологий, Волгоградский государственный университет, просп. Университетский, 100, 400062 г. Волгоград, Российская Федерация; ведущий научный сотрудник, Институт демографических исследований ФНИСЦ PAН, ул. Фотиевой, 6, к. 1, 119333 г. Москва, Российская Федерация, vasilevaen@volsu.ru, https://orcid.org/0000-0002-0460-5539

Екатерина Александровна Князькова, кандидат политических наук, старший научный сотрудник отдела семьи и семейно-демографической политики, Институт демографических исследований ФНИСЦ РАН, ул. Фотиевой, 6, к. 1, 119333 г. Москва, Российская Федерация; доцент социологического факультета, Российский государственный гуманитарный университет, Миусская площадь, 6, 125993 г. Москва, Российская Федерация, eapavlova@bk.ru, https://orcid.org/0000-0002-4032-1656

Елена Олеговна Данилова, кандидат социологических наук, старший преподаватель кафедры социологии и социальных технологий, Волгоградский государственный университет, просп. Университетский, 100, 400062 г. Волгоград, Российская Федерация, danilovaelena@volsu.ru, https://orcid.org/0000-0002-2859-2226 